\title{
In vitro Evaluation of Chemical Composition and Various Biological Activities of Ficus carica Leaves Extracts
}

\section{Ficus carica Yaprak Ekstrelerinin Kimyasal Bileşiminin ve Çeşitli Biyolojik Aktivitelerinin Ín Vitro Değerlendirilmesi}

\section{ABSTRACT}

Objectives: The present study was aimed to investigate the inhibitory activities of enzymes, related with diabetes mellitus and Alzheimer's disease of the methanol and water extracts of $F$. carica leaves extracts. The bioactive compounds, anticancer, antioxidant, and antimicrobial effects of the extracts were also investigated.

Materials and Methods: The bioactive compounds in the extracts were determined by gas chromatography-mass spectrometry (GC-MS) method. The antioxidant activity was evaluated by DPPH, ABTS radical scavenging, total phenol and flavonoid content, ferric reducing power and iron chelating method. The anticancer, anticholinesterase, and antimicrobial effects were investigated using the XTT assay, Ellman method, and microdilution technique, respectively.

Results: Our results showed that between the water and methanol extracts there was a difference in terms of chemical composition. The antioxidant results suggested that both extracts have strong antioxidant activity. Similarly, both extracts showed strong $\alpha$-glucosidase and $\alpha$-amylase inhibition activity, while the water extract has higher inhibition activity than the methanol extract against acetylcholinesterase (AChE) and butyrylcholinesterase (BChE). The methanol extract of $F$. carica exhibited significant anticancer activity on MDA-MB-231 cells and showed moderate antimicrobial activities against Escherichia coli and Staphylococcus aureus.

Conclusion: Our results suggest that $F$. carica leaves could be a valuable source for developing a promising therapeutic agent in cancer, diabetes, and Alzheimer's disease.

Keywords: Ficus carica; Alzheimer's Disease; Diabetes; Antioxidant Activity; Anticancer and Antimicrobial Activities.

\section{ÖZET}


Amaç: Bu çalışmada, F. carica yapraklarına ait su ve metanol ekstrelerinin diyabet ve Alzheimer hastalığı ile ilişkili enzimlerin inhibisyonu üzerine etkisinin araştırılması amaçlanmıştır. Ayrıca, ekstrelere ait biyoaktif bileşenler, antikanser, antioksidan ve antimikrobiyal etkiler de araştırımıştır.

Gereç ve Yöntemler: Ekstrelerdeki biyoaktif bileşikler gaz kromatografisi-kütle spektrometresi (GC-MS) metodu ile belirlenmiştir. Antioksidan aktivite, DPPH, ABTS radikal süpürücü, toplam fenol ve flavonoid içeriği, ferrik indirgeme gücü ve demir şelasyon yöntemleriyle değerlendirilmiştir. Antikanser, antikolinesteraz ve antimikrobiyal etkinlikler ise sırasıyla XTT yöntemi, Ellman yöntemi ve mikrodilüsyon tekniği yöntemi ile belirlenmiştir.

Bulgular: Elde ettiğimiz sonuçlar su ve metanol ekstreleri arasında kimyasal bileşim açısından farklılık olduğunu ve her iki ekstrenin de gûbçü antiokşidan aktiviteye sahip olduğunu göstermiş̧tir. Benzer şekilde, her iki ekstrede güçlü $\alpha$-glikozidaz ve $\alpha$-amilaz aktivite gösterirken, su ekstresi metanole göre daha güçlü asetilkolinesteraz ve butirilkolinesteraz inhibisyon etkiye sahiptir. F. carica metanol ekstresi MDA-MB-231 hücreleri üzerinde güçlü antikanser etki, Escherichia coli ve Staphylococcus aureus'e karşı ise orta düzeyde antimikrobiyal etki göstermiştir.

Sonuç: Bulgularımız, F. carica yapraklarının kanser, diyabet ve Alzheimer hastalığında umut verici bir terapötik ajan geliştirmek için değerli bir kaynak olabileceğini düşündürmektedir.

Anahtar kelimeler: Ficus carica, Alzheimer hastalığı, diyabet, antioksidan aktivite, antikanser ve antimikrobiyal aktivite.

\section{INTRODUCTION}

Ficus carica belongs to the Moraceae family and is a native of southwest Asia. It is cultivated in worldwide and has been traditionally used in indigenous systems of medicine, such as Ayurveda and homeopathy for cardiovascular and hypertensive diseases. ${ }^{1,2}$ Fig fruit (Ficus carica L.) possess several vitamins, minerals, carbohydrates, and phenolic compounds, for instance, phenolic acids, flavonols, and flavones, which play the significant role in its therapeutic efficiency. ${ }^{3,4,5}$ Many reports 
also exhibited that polyphenolic ingredient of fruits has an antiinflammatory, antioxidant, antimicrobial, and anticancer effects. ${ }^{6}$

In recent years, due to increasing cancer cases and similar health problems, the demand for products with antioxidant properties is increasing day by day. In this context, plants that have antioxidant and anticancer properties have attracted the wide attention. It is well known that antioxidants have significant inhibitory effects on various free radical species and also neutralize non-radical species such as hydrogen peroxide. Additionally, they can prevent the production of many reactive oxygen species in various diseases including cancer and diabetes, etc. ${ }^{7,8}$

Diabetes mellitus is a chronic metabolic disease that causes elevation of blood sugar due to insufficient insulin secretion or insulin resistance. $\alpha$-glucosidase and $\alpha$-amylase inhibitors are used in some cases to control the level of postprandial blood glucose in the treatment of diabetes mellitus. These two enzymes are involved in the conversion of food polysaccharides into monosaccharides. However, the synthetic hypoglycemic agents have been reported for several side effects such as hepatotoxicity and gastrointestinal disorders. Accordingly, researchers are looking for new potential with less adverse effect antidiabetic agents from natural sources. ${ }^{9}$

Alzheimer's disease (AD) is the most common form of dementia, characterized by memory loss and other cognitive disabilities. Down-regulation of acetylcholine are associated with the development of AD. Acetylcholinesterase (AChE) and butyrylcholinesterase (BChE) are responsible for the hydrolytic metabolism of the neurotransmitter acetylcholine (ACh) into choline and acetate in the brain. Based on the cholinergic hypothesis, a defect in the cholinergic system is involved in the development of $A D .{ }^{10}$ Therefore, the current treatment strategy for the $A D$ is directed to the inhibition of AChE and BChE. There are some AChE inhibitors such as galanthamine, physostigmine, and tacrine approved for treatment of AD. However, these drugs have side effects including hepatotoxicity and limiting the use of these drugs in clinical practice. Hence, researchers are looking for new treatments to control the disease and improve the quality of life for people with the AD from natural resources.

Cancer is one of the most significant health issues worldwide and second leading cause of death globally after cardiovascular diseases. ${ }^{11}$ Conventional treatments used 
in the clinic such as chemotherapy, surgery, and radiotherapy have several serious side effects and can cause damage to non-cancerous tissues. ${ }^{12}$ Besides, due to increasing drug resistance especially in cancer treatment, plants have become increasingly important in the search for new chemotherapeutic agents. In the clinic, there are many antitumor drugs derived from plants such as vincristine, vinblastine (Catharanthus sp.), paclitaxel (Taxus sp.), and epipodophyllotoxins (Podophyllum sp.). ${ }^{13}$ Furthermore, researches continue at a great pace for the discovery of new drugs with more effective and less side effect profiles. F. carica is one of the medicinally important plants that has therapeutic potentials. Many researchers have reported that antimicrobial effects of $F$. carica leaf extracts against oral bacteria, nosocomial infectious agents, food poisoning bacteria, fungi and viruses. ${ }^{4-17}$ Moreover, the fruit, root, and leaves of $F$. carica are utilized medicinal purpose for treat various diseases such as respiratory, gastrointestinal, anti-inflammatory, and antispasmodic remedy. ${ }^{18}$

To the best of our knowledge, despite the fruit and different parts of this plant has been mostly studied, the number of study on leaves is limited. Thus, this study was carried out to evaluate differences between water and methanol extracts for antioxidant, antimicrobial, enzyme inhibition activity (AChE, BChE, $\alpha$-glucosidase, and $\alpha$-amylase), and anticancer properties in vitro. It is also aimed to analyze the content of extracts by the gas chromatography-mass spectroscopy (GC-MS) analysis.

\section{EXPERIMENTAL}

This study was conducted in the laboratories of the Faculty of Pharmacy, Cumhuriyet University, Sivas in 2018. The plant materials were collected in July, 2017 from the wild flora of Saklıkent/Fethiye. The experiments were performed in completely randomized design with three replications.

\section{Preparation of Extracts}

The plant leaves were milled with a grinder than dried to a shade and dry leaves were ground in a blender (Blue house). $10 \mathrm{~g}$ of the leaf was soaked in $50 \mathrm{~mL}$ methanol (Sigma) and water for $24 \mathrm{~h}$ with intermittent shaking. At the end of the extraction, it was filtrated through No. 1 whatman filter paper. The filtrate was concentrated to dryness under reduced pressure in a rotary evaporator at $40{ }^{\circ} \mathrm{C}$ and this was repeated three times. The obtained extracts were analyzed using GC-MS. ${ }^{19}$ 


\section{In vitro Antioxidant Activity}

The antioxidant activity of the methanol and water extracts of $F$. carica leaves was tested using different methods namely as DPPH, ABTS radical scavenging activity, total phenol/flavonoid content, ferric reducing power, and iron chelating method.

\section{DPPH Radical Scavenging Activity}

The free radical scavenging activity by methanol extracts was performed according to the method reported by Salihoglu et al..$^{20}$ The $150 \mu \mathrm{L}$ of the extract was mixed with 50 $\mu \mathrm{L}$ of $1.0 \times 10^{-3} \mathrm{M}$ freshly prepared $\mathrm{DPPH} \cdot$ methanol solution in 96 -well plates. Methanol was used as the control of the experiment. After $30 \mathrm{~min}$ of incubation at $25^{\circ} \mathrm{C}$, the reduction of the DPPH• was measured reading the absorbance at $517 \mathrm{~nm}$ with the microplate reader (Epoch, USA). Butylated hydroxytoluene (BHT) used as the positive controls and the percentage inhibition was calculated with the following equation:

$\%$ Inhibition $=$ [Absorbance of control - Absorbance of test sample / Absorbance of control] $\times 100$

\section{ABTS radical scavenging activity}

For determining of $A B T S$ radical scavenging activity of the extracts, followed by the method of Re et al. ${ }^{21}$ with slight modification. The stock solution of ABTS was made by reacting $7 \mathrm{mM}$ ABTS solution with $2.4 \mathrm{mM}$ of potassium persulfate solution in equal volume for $16 \mathrm{~h}$. Working solution was then prepared by diluting the stock ABTS•+ solution with methanol to give an absorbance of $0.7 \pm 0.02$ units at $734 \mathrm{~nm}$ using a microplate reader (Epoch, USA). In each experiment, the ABTS •+ solution was prepared freshly. $50 \mu \mathrm{L}$ of extract was mixed with $150 \mu \mathrm{L}$ ABTS $\cdot{ }^{+}$working solution and stand for $10 \mathrm{~min}$ at the dark place. All the analyses were conducted in triplicate and the results expressed as the mean \pm standard deviation. Appropriate blanks (methanol) and standard (BHT) were run simultaneously.

Determination of Total Phenolic Content (TPC)

In order to measure the total phenolic content in the extracts, spectrophotometric Folin-Ciocalteu method was used as previously described by Clarke et al. ${ }^{22}$, with slight modification. Briefly, $20 \mu \mathrm{L}$ of extract in DMSO was mixed with $100 \mu \mathrm{L}$ freshly $1 / 10$ diluted $\mathrm{F}-\mathrm{C}$ reagent with distilled water. After five min, the solution was mixed with 80 $\mu \mathrm{L}$ of $7.5 \% \mathrm{Na}_{2} \mathrm{CO}_{3}$ solution, and incubated for $30 \mathrm{~min}$ at $25^{\circ} \mathrm{C}$. The measurement of 
absorbance was performed at $650 \mathrm{~nm}$ in a microplate reader (Epoch, USA). All the analyses were performed in triplicate and the results expressed as the mean \pm standard deviation. Appropriate blanks (DMSO) and standard (gallic acid in DMSO) were run simultaneously, after which the total phenolics content (TPC) was calculated as milligrams gallic acid equivalents per gram of dry extract.

\section{Estimation of Total Flavonoid Content (TFC)}

For determination of total flavonoid content, the aluminum chloride colorimetric method was used as previously described by Molan et al. ${ }^{23}$ using catechin as the reference standard. Briefly, $25 \mu \mathrm{L}$ of $1 \mathrm{mg} / \mathrm{mL}$ test sample solution, $100 \mu \mathrm{L}$ of dd. $\mathrm{H}_{2} \mathrm{O}$ and $7 \mu \mathrm{L}$ of $5 \% \mathrm{NaNO}_{2}$ were mixed together in 96 -well plates. After 15 min of incubation at room temperature, $7 \mu \mathrm{L}$ of $10 \% \mathrm{AlCl}_{3}$ was added. After $5 \mathrm{~min}, 50 \mu \mathrm{L}$ of $1 \mathrm{M} \mathrm{NaOH}$ and $60 \mu \mathrm{L}$ of distilled water were added to each well. Then the absorbance was measured at 490 $\mathrm{nm}$ in a microplate reader (Epoch, USA). All determinations were carried out in triplicates. The content of total flavonoids was expressed as $\mathrm{mg}$ of catechin equivalent per $g$ of the dry weight of extract.

\section{Iron chelating activity}

The iron chelating activity of the extracts was determined according to their interaction with the formation of the ferrozine- $\mathrm{Fe}^{2+}$ complex. Previously described procedures were used. ${ }^{24}$ Briefly, a mixture of $200 \mu \mathrm{L}$ of $0.1 \mathrm{mM} \mathrm{FeSO}_{4}, 200 \mu \mathrm{L}$ of extract, and 400 $\mu \mathrm{L}$ of $0.2 \mathrm{mM}$ ferrozine was allowing the mixture to react at $25^{\circ} \mathrm{C}$. The mixture absorbance was read after $10 \mathrm{~min}$ of incubation at $562 \mathrm{~nm}$. EDTA was used as the positive control.

Ferric reducing antioxidant power (FRAP) assay

The FRAP method is used as a reducing agent in redox colorimetric reactions of antioxidants. The FRAP assay was conducted according to the previously reported method with a slight modification. ${ }^{25,26}$ The stock solution of each extract was prepared in DMSO. The working solution of FRAP reagent was prepared by mixing $0.3 \mathrm{M} \mathrm{pH} 3.6$ acetate buffer, a solution of $10 \mathrm{mM}$ 2,4,6-tripyridyl-s-triazine (TPTZ) in $0.04 \mathrm{M} \mathrm{HCl}$ and $0.02 \mathrm{M} \mathrm{FeCl}_{3}$ solution in the ratio of 10:1:1 at the time of use. All solutions were prepared fresh on the day of the experiment. $30 \mu \mathrm{L}$ of the sample solution and $270 \mu \mathrm{L}$ of FRAP working solution were mixed together in 96 -well plates and warmed at $37^{\circ} \mathrm{C}$ for $4 \mathrm{~min}$. All determinations were performed in triplicate. The absorbance was 
measured at $593 \mathrm{~nm}$. A standard calibration curve was prepared using different concentrations of $\mathrm{FeSO}_{4}$ solution. The results were expressed as FRAP value.

\section{Acetylcholinesterase/butyrylcholinesterase inhibition assay}

The assay was carried out according to the Ellman method ${ }^{27}$ as follows. The mixture consisting of $20 \mu \mathrm{L}$ of test sample/reference standard of various concentrations, 140 $\mu \mathrm{L}$ of $0.1 \mathrm{mM}$ phosphate buffer ( $\mathrm{pH} 6.8$ ), $10 \mu \mathrm{L}$ of $3 \mathrm{mM} \mathrm{5,5'-dithio-bis-nitrobenzoic}$ acid (DTNB) and $20 \mu \mathrm{L}$ of enzyme $(0.22 \mathrm{U} / \mathrm{mL}$ for acetylcholinesterase/ $0.1 \mathrm{U} / \mathrm{mL}$ for butyrylcholinesterase) prepared in phosphate buffer was incubated for 5 min at $25^{\circ} \mathrm{C}$. Following preincubation, $10 \mu \mathrm{L}$ of the substrate $(0.71 \mathrm{mM}$ acetylthiocholine iodide $/ 0.2$ $\mathrm{mM}$ butyrylthiocholine chloride in phosphate buffer) was added to start the reaction and incubated again for $10 \mathrm{~min}$. The developed yellow color was measured at $412 \mathrm{~nm}$ (Epoch, USA). Galanthamine was used as the positive control.

\section{Alpha-glucosidase inhibition activity}

The $\alpha$-glucosidase inhibition method was followed by Kumar et al. ${ }^{28}$ Acarbose was used as a positive control, while phosphate buffer was used as a negative control in place of the sample. Each concentration was carried out in triplicate. $25 \mu \mathrm{L}$ of sample solution diluted with buffer was mixed with $25 \mu \mathrm{L}$ of $\alpha$-glucosidase $(0.5 \mathrm{U} / \mathrm{mL})$, and incubated for approximately $10 \mathrm{~min}$ at $25^{\circ} \mathrm{C}$. Then $25 \mu \mathrm{L}$ of $0.5 \mathrm{mM}$ 4-nitrophenyl- $\beta$ D-glucuronide (pNPG) was added to each well as substrate and incubated for a 30 min at $37^{\circ} \mathrm{C}$. After the incubation period, $100 \mu \mathrm{L}$ of $0.2 \mathrm{M}$ sodium carbonate was added to terminating the reaction and the absorbance was read at $405 \mathrm{~nm}$.

\section{Alpha-amylase inhibition activity}

The $\alpha$-amylase inhibition method was followed by Kumar et al. ${ }^{29}$ Acarbose was used as a positive control, while phosphate buffer (0.02 M PBS, pH 6.9) was used as a negative control in place of the sample. Each sample was carried out in triplicate with different concentrations. The reaction mixture containing $50 \mu \mathrm{L}$ of sample solution diluted with buffer, and $25 \mu \mathrm{L}$ of $\alpha$-amylase from porcine pancreases $(0.5 \mathrm{mg} / \mathrm{mL})$ was incubated for approximately $10 \mathrm{~min}$ at $25^{\circ} \mathrm{C}$. Then $50 \mu \mathrm{L}$ of freshly prepared $0.5 \%$ starch solution ( $\mathrm{w} / \mathrm{v})$ was added to each well as substrate and incubated for a $10 \mathrm{~min}$ at $25^{\circ} \mathrm{C}$. After the incubation period, $100 \mu \mathrm{L}$ of $1 \% 3,5$-dinitrosalicylic acid (DNS) color reagent was added as the color reagent and heated in a water bath for $10 \mathrm{~min}$. The absorbance was read at $540 \mathrm{~nm}$. 


\section{Antimicrobial activity}

\section{Microdilution Broth Method}

The microdilution broth method with a slight modification was used to determine the Minimum Inhibitory Concentration (MIC) of the water and methanol extracts of $F$. carica against the microorganism. ${ }^{30}$ In this study, Staphylococcus aureus (ATCC 29213), Enterococcus faecalis (ATCC 29212), Pseudomonas aeruginosa (ATCC 27853), Escherichia coli (ATCC 25922), Klebsiella pneumonia (ATCC 13883) and Candida albicans (ATCC 10231) strains were used. The extracts were dissolved in 50\% dimethyl sulfoxide (DMSO) and the final concentrations of the extracts were $50 \mathrm{mg} / \mathrm{mL}$. Mueller Hinton Broth (Accumix ${ }^{\circledR}$ AM1072) and Saboraud Dextrose Broth (Himedia ME033) was used for dilution bacteria and C.albicans culture's, respectively. In the first row of the plate, $90 \mu \mathrm{L}$ broth was added into the wells and $50 \mu \mathrm{L}$ broth was added to all other wells. The 11th wells were used as the reproductive controls and $100 \mu \mathrm{L}$ of broth was added. In the first line of the microtiter plate, $10 \mu \mathrm{L}$ extract was added and serial two-fold dilutions were prepared from the diluted extracts to give concentrations ranging from 2.5 to $0.004 \mathrm{mg} / \mathrm{mL}$. The bacteria and fungi suspension $(50 \mu \mathrm{L})$ were added on prepared samples. Final inoculum size was $5 \times 10^{5} \mathrm{CFU} / \mathrm{mL}$ at bacteria and 0.5-2.5 $\times 10^{3} \mathrm{CFU} / \mathrm{mL}$ at $C$. albicans every well (CLSI, 2002, CLSI, 2012). The plates with the added bacteria and C. albicans were incubated at $37^{\circ} \mathrm{C}$ and $35^{\circ} \mathrm{C}$ for $16-24$ h, respectively. Afterward, to observe microbial growth $50 \mu \mathrm{L}, 2,3,5-$ Triphenyltetrazolium chloride (TTC) (Meck, Germany) was added to each well. The microtiter plates were further incubated at $37^{\circ} \mathrm{C}$ for $2 \mathrm{~h}$. The first well which density of formazon's red color reduced was accepted as MIC value. The experiment was performed in duplicate and the standard deviation was zero.

\section{Cytotoxicity}

\section{Cell lines and reagents}

Human breast adenocarcinoma MDA-MB-231 cells and mouse fibroblast cells L929 were obtained from American Type Culture Collection (ATCC, Manassas, VA). Dulbecco's modified Eagle's medium (DMEM), fetal bovine serum (FBS) and sterile phosphate buffer saline (PBS) were purchased from PAA Ltd. (France). Trypsin-EDTA was supplied from Biological Industries Ltd. (Haemek, Israel). DMEM without phenol 
red and L-glutamine-penicillin-streptomycin solutions were from Sigma-Aldrich (Steinheim am Albuch, Germany). XTT reagent (2,3-bis-(2-methoxy-4-nitro-5sulfophenyl)-2H-tetrazolium-5-carboxanilide) was purchased from Roche Diagnostic. Cell culture

The cytotoxicity of the $F$. carica leaf extracts was tested against MDA-MB-231 and L929 cell lines. During the experiments, both cell lines were grown in DMEM supplemented with $10 \%$ FBS, $1 \%$ L-glutamine, $100 \mathrm{IU} / \mathrm{mL}$ penicillin and $10 \mathrm{mg} / \mathrm{mL}$ streptomycin in $25 \mathrm{~cm}^{2}$ polystyrene flasks and maintained in a humidified atmosphere with $5 \% \mathrm{CO}_{2}$ at $37{ }^{\circ} \mathrm{C}$. Growth and morphology were monitored, the culture medium was changed every two days, and cells were passaged when they had reached 80$90 \%$ confluence.

\section{Cell viability assay}

The antiproliferative activity of the $F$. carica leaf extracts was evaluated using the XTT colorimetric assay against the MDA-MB-231 and L929 cells. Extracts were dissolved in DMSO and diluted in DMEM prior to treatment. Initially, cancer and control cells were seeded at a density of $5 \times 10^{3}$ cells per well in 96-well culture plates in $100 \mu \mathrm{L}$ of culture medium and were allowed to attach overnight before treatment. The next day, these cells were treated with serial concentrations $(0.0625,0.125,0.25,0.5,1 \mathrm{mg} / \mathrm{mL})$ of $F$. carica for $24 \mathrm{~h}$. Besides, non-treated cells and cells treated with DMSO (0.5\%) were used as negative control and solvent control respectively. After that, the treatment medium was removed and wells were washed twice with $200 \mu \mathrm{L}$ phosphate buffered saline (PBS). At the end of these periods, for determination of living cells, $100 \mu \mathrm{L}$ DMEM without phenol red and $50 \mu \mathrm{L}$ XTT labeling mixture were added to each well and then the plates were incubated for another $4 \mathrm{~h}$. The absorbance of XTT-formazan was measured using micro plate (ELISA) reader at $450 \mathrm{~nm}$ against the control (the same cells without any treatment). All experiments were performed in three independent experiments and the cell viability was expressed in \% related to control (100\% of viability).

\section{Statistical Analysis}

Data obtained from in vitro antioxidant and antidiabetic activity were expressed as the mean \pm standard deviation (SD). Cytotoxicity results were evaluated statistically using one-way analysis of variance (ANOVA) at $95 \%$ confidence levels for multiple 
comparisons. The Tukey test was used as the post-hoc test. $\mathrm{P}$ values less than or equal to 0.05 were considered to be statistically significant. The $50 \%$ inhibitory concentrations of the extract and reference compounds were calculated through an extract dose-response curve on GraphPad Software (San Diego, CA, USA).

\section{RESULTS AND DISCUSSION}

GC-MS analysis of the water and methanol extracts of F. carica

The chemical compositions of the water and methanol extracts of $F$. carica leaves were studied using GC-MS and results are shown in Table 1. According to the GC-MS results, the more different components were obtained in the methanofextract than the aqueous extract of $F$. carica. Namely, six and twenty-eight different compounds were determined in the water and methanol extracts respectively. While the most abundant component are benzene, methoxy- (3.32\%), 4-Methyl-1,4-heptadiene (6.85\%), 1Pentene, 2,3-dimethyl- (2.72\%) for the water extract, $2 \mathrm{H}$-Furo[2,3-H]-1-benzopyran-2one $(53.64 \%)$, bergapten (19.27\%), 9,12,15-Octadecatrienoic acid, methyl ester, $(Z, Z, Z)-(4.05 \%)$ for the methanol extract.

When the extracts of the $F$. carica leaves were compared, we can inform that the solubility of the methanol extracts much greater than the water extracts, because the number of components is much higher in the methanol extracts. However, when we compare the enzyme inhibition activities, the water extracts were showed higher inhibition activities than the methanol extracts (Table 2). This is most likely caused by the water extract components. It is also interesting that almost none of these components are present in the methanol extract. Likewise, in the study conducted by Konyalıoğlu ${ }^{31}$ the amount of alpha-tocopherol in fig leaves was determined by HPLC and correlated with antioxidant activity. In our study, GC-MS analysis of the F. carica leaves shows that antioxidant vitamin alpha-tocopherol (vitamin E) was found in the methanol extract.

In vitro antioxidant activity

In vitro radical scavenging activity

In some physiopathologic circumstances, there is an excessive production of free radicals leading to the occurrence of oxidative stress. This later is related to the appearance of many diseases including Alzheimer's diseases, cardiovascular disease, 
and cancer. ${ }^{7,8}$ Natural antioxidants inhibit their activity by different mechanisms such as scavenging of reactive oxygen species, metal chelating, activation of antioxidant enzymes, and inhibition of oxidase. Therefore, it is necessary to use different methods to evaluate antioxidant activity of extracts in plants. Previous studies have shown that the fig of $F$. carica has antioxidant activity. ${ }^{32}$ In our study, leaf extract of the F. carica scavenged DPPH and ABTS radical in concentration dependent manner. As shown in Figure 1 ( $a$ and $b$ ), the $I C_{50}$ of ABTS radical scavenging activity of the methanol and water extract was found $559.39 \mu \mathrm{g} / \mathrm{mL}$ and $428.51 \mu \mathrm{g} / \mathrm{mL}$, while DPPH scavenging activity was found $1.45 \mathrm{mg} / \mathrm{mL}$ and $1.83 \mathrm{mg} / \mathrm{mL}$, respectively.

The total phenolics ( $\mathrm{mg} \mathrm{GAE} / \mathrm{g}$ of sample) and flavonoid ( $\mathrm{mg} \mathrm{CE} / \mathrm{g}$ of sample) in the different extract of the $F$. carica leaves are exhibited in Figure 1C. F. carica leaf methanol extract (16.11 mg GAE/g) exhibited higher phenolic contents as compared to water extract $(6.29 \mathrm{mg} \mathrm{GAE} / \mathrm{g})$, while the total flavonoid content is almost the same as that of methanol (11.29 mg CE/g) and water (11.06 mg CE/g) extract. The phenolic compounds in fig leaves were quantitatively determined using HPLC-DAD by Teixeira et al. ${ }^{34}$ We also achieved similar results using a different method in our study. In another study by Ali et $\mathrm{al}^{33}$, it has been shown that antioxidant and anti-inflammatory activity of fig leaves are associated with flavonoids and phenolic compounds found in the leaves.

It is well known that the ferrous and cupric ions stimulate lipid oxidation by breaking down hydrogen and lipid peroxides to reactive free radicals via the fenton reaction. Therefore, metal chelating agents playing important role in terms of retarding the radialic degradation by reducing the concentration of transition metal. ${ }^{35}$ According to our results, water extracts exhibited better iron chelating activity than methanol extract (Figure 1e).

In the FRAP assay, the reductants (antioxidants) presented in the extract reduce a $\mathrm{Fe}^{3+}-\mathrm{TPTZ}$ complex to form blue colored $\mathrm{Fe}^{2+}-\mathrm{TPTZ}$. The change of absorbance at $593 \mathrm{~nm}$ is proportional to the FRAP value of the antioxidants in the sample. ${ }^{36}$ The results of FRAP assay are given in Figure $1 \mathrm{~d}$. In this assay, the highest activity was noted for methanol extract than water extract at higher concentration, but the ferric reducing power was same at the lower concentration. 
The methanol and water extracts prepared from $F$. carica leaves were evaluated for their inhibitory effects against AChE and BChE, which are Alzheimer's disease-related enzymes. The water extract exhibited stronger activity and showed $63 \%$ and $73 \%$ inhibition of $\mathrm{AChE}$ and $\mathrm{BChE}$, which was lower than the standard drug galanthamine (with 93\% and $90 \%$ inhibition) at the same concentration (Table 2). According to the reported by Ahmad et al. ${ }^{37}$, the $n$-butanol fractions displayed best anti-AChE activity, while ethyl acetate soluble fraction demonstrated best anti-BChE activity among different solvent fractions of $F$. carica fruits. In the study of Orhan et al. ${ }^{38}$, the $n$-hexane and acetone extracts of leaves exhibited a notable inhibition activity against both the $\mathrm{AChE}$ and BChE. However, different from this one, in our study the aqueous extract was found to be more active than the methanol in terms of these two enzyme inhibitions. This may be due to the more polar compounds present in the aqueous extract active against AChE and BChE enzyme inhibition.

In vitro a-glucosidase and a-amylase enzyme inhibition activity

It is known that $\alpha$-amylase and $\alpha$-glucosidase are enzymes that catalyze the hydrolysis of polysaccharides and disaccharides to monosaccharides. The inhibition of these two enzymes hinders the rapid uptake of blood glucose levels by delaying the digestion of carbohydrates. ${ }^{39}$ The results of the inhibitory activity of the $F$. carica leaf methanol and water extract against $\alpha$-glucosidase and $\alpha$-amylase enzyme are presented in Table 2 . When compared each other, the water extract $(69.56 \%$ and $69.08 \%)$ was found to be higher than the methanol extract $(64.93 \%$ and $67.32 \%)$ in inhibit $\alpha$-glucosidase and $\alpha$ amylase enzyme activity respectively, besides both of the extracts was found to be a potential inhibitor against $a$-glucosidase and $a$-amylase compared with standard antidiabetic drug acarbose (57.56\% and $58.4 \%)$ at the same concentration $(2 \mathrm{mg} / \mathrm{ml})$. In a recent study, similar antidiabetic activities were reported for the ethyl acetate and ethanol extracts of $F$. carica fruit. ${ }^{39} \mathrm{In}$ another study, the ethyl acetate extract of $F$. carica leaves showed antidiabetic activity by stimulating the insulin production from the regenerated pancreas beta cells. ${ }^{40}$ Similar results were reported for the water and methanol extract of $F$. carica leaves in our study.

\section{Antimicrobial activity}


The antimicrobial activities of $F$. carica methanol and water extracts against Staphylococcus aureus, Enterococcus faecalis, Pseudomonas aeruginosa, Escherichia coli, Klebsiella pneumonia, and C. albicans were detected using the microdilution technique at the concentration range 0.156 to $2.5 \mathrm{mg} / \mathrm{mL}$ (Table 3 ). It has been reported that antimicrobial activity of plant extracts have been evaluated significant when the MIC value less than or equal to $0.1 \mathrm{mg} / \mathrm{mL}$, moderate when $0.1<$ MIC $\leq 0.625 \mathrm{mg} / \mathrm{mL}$, and weak when MIC value greater than $0.625 \mathrm{mg} / \mathrm{mL} .{ }^{41}$ According to these criteria, the methanol extract of $F$. carica showed moderate antimicrobial activities against the E. coli $(0.625 \mathrm{mg} / \mathrm{mL})$ and $S$. aureus $(0.156 \mathrm{mg} / \mathrm{mL})$ and weak antimicrobial activity against the other bacteria and C.albicans $(\geq 2.5 \mathrm{mg} / \mathrm{mL})$. Similarly, the water extract of $F$. carica displayed moderate antimicrobial activity on the $S$. aureus $(0.625 \mathrm{mg} / \mathrm{mL})$ and weak antimicrobial activity against other bacteria and C.albicans $(\geq 2.5 \mathrm{mg} / \mathrm{mL}$ ).

F. carica methanol extract has been studied against various bacteria and showed moderate to strong antibacterial activity. An in vitro study, Jeong et al. reported that the $F$. carica methanol extract had strong antibacterial activity on oral bacteria. ${ }^{42}$ In another study Keskin et al., investigated the antimicrobial activity of different extracts of $F$. carica. Their study reported that the MIC values of the methanol and aqueous extracts of $F$. carica against bacteria and $C$. albicans were between MIC 25-400< $\mu \mathrm{g} / \mathrm{mL}$ and MIC $200-400<\mu \mathrm{g} / \mathrm{mL}$, respectively. ${ }^{43}$ In the present study, E. coli and $S$. aureus were detected more susceptible to the methanol extract. Our results revealed that the methanol and water extract of $F$. carica exhibited weak antimicrobial effect against other bacteria and C. albicans.

Cell Viabilty

XTT cell proliferation assay was used to evaluate the antiproliferative effects of the water and methanolic extracts of $F$. carica on MDA-MB-231 and L929 cell lines. As shown in Figure 2, the methanol extract at all concentration significantly inhibited MDAMB-231 cell proliferation $(p<0.05)$ in a dose-dependent manner $\left(\mathrm{IC}_{50}=0.081 \mathrm{mg} / \mathrm{mL}\right)$. On the other hand, concentration of $1 \mathrm{mg} / \mathrm{mL}$ of the water extract moderately decreased the cell viability $\left(\mathrm{IC}_{50}>1 \mathrm{mg} / \mathrm{mL}\right)(\mathrm{p}<0.05)$. However, neither extract exhibited any significant cytotoxicity on the L929 cell line at the concentrations range (1-0.0625 mg/mL). 
Our cytotoxicity results clearly indicated that the methanol extract is more toxic than the water extract of $F$. carica. This may be due to the fact that the methanol extract has richer active ingredients than the water extract, as shown in Table 1. Additionally, the anticancer effects may be associated with antioxidant features due to its polyphenolic components quantity (Figure 1). To the best of our knowledge, this is the first study of the anticancer effect of fig leaf extracts on MDA-MB-231. However, different parts of F. carica and different extracts of fig leaf have already been found to be cytotoxic on various cancer cells such as, stomach and cervix. .,44 $^{2}$

\section{CONCLUSION}

Overall, in this study, the components and antioxidant, antimicrobial, anticancer, enzymes inhibition, and antidiabetic effects of the F. carica leaf methanol and water extracts were investigated. Despite there were several antioxidant activities of $F$. carica leaves, to our knowledge there are no reports on the comparative study of extracts with different polarity as well as other antioxidant methods such as iron chelating and ferric reducing power. Our results indicated that especially the methanol extract has strong anticancer, antioxidant and anti-diabetic activities. There is a correlation between anticancer and antioxidant activity and total phenolic content. Moreover, the richer chemical content of the methanol extract may be associated with higher biological activity. Consequently, the methanolic extract of the leaf of $F$. carica may be considered as a potential therapeutic agent in cancer and diabetes mellitus. However, further studies, particularly in vivo experiments, are needed to verify these effects 